\title{
The full financial costs of irrigation services: A discussion on existing guidelines and implications for smallholder irrigation in South Africa
}

\author{
S Perret ${ }^{1,2 *}$ and M Geyser ${ }^{2}$ \\ ${ }^{1}$ Centre de Coopération Internationale en Recherche Agronomique pour le Développement, France \\ ${ }^{2}$ University of Pretoria, Department of Agricultural Economics, Extension and Rural Development, Pretoria, South Africa
}

\begin{abstract}
Considering water as an economic good entails, among other requisites, properly assessing the cost incurred by supplying and managing the resource, and the required infrastructure thereof. Regarding irrigation, the International Commission for Irrigation and Drainage (ICID) set up a method for assessing the full financial costs, in the form of guidelines. This paper investigates the applicability of these guidelines in smallholder irrigation conditions in developing countries.

The paper first presents the specific conditions and features of such a sector, with emphasis on South African examples. Several specific issues are identified and discussed, such as the lack of records on infrastructure and initial costs, the multiple purpose and actual uses of certain equipment and infrastructure, the shift in purpose of others over time, the inclusion of certain small, yet indispensable equipment in the calculation, the partial refurbishment works on particular assets, and the lack of a standard basis for calculation under tropical, developing conditions (e.g. on service life, maintenance requirements). Secondly, after a brief review of current frameworks, concepts and terminology, the paper attempts to apply the existing guidelines developed by ICID for evaluating financial costs of irrigation services on a case study in South Africa. The results suggest that the application of the guidelines is feasible, provided that some adapted data and available information replace the original set, especially for capital costs. This applies to the discount rate, calculation of the current value, and estimation of the service life of infrastructure and equipment. In particular, several scenarios have been tested in order to identify a surrogate to the discount rate. The average yield on Negotiable Certificates of Deposit (NCD) is suggested as a surrogate for treasury bills and hence as a substitute for the discount rate. The case study demonstrates the high costs of irrigation services compared to the low income derived from irrigation production in smallholder schemes and hence the need for renewed public intervention and subsidisation, especially on account of the current context of management transfer, privatisation, and liberalisation. The paper suggests a shift in the underlying policy and societal mindset about the water charging system for smallholder irrigation. Cost recovery and water charges should not be considered as being a further burden or deterring factor for smallholder irrigation, but rather as an incentive towards increasing production and ultimately improving their contribution to the country's economy.
\end{abstract}

Keywords: financial costs, irrigation, South Africa, evaluation, smallholder agriculture, economic viability

\section{Introduction}

\section{Water as an economic good: what about irrigation water?}

The overall level of spending on water-related infrastructure in developing countries amounts to about US\$ 65 billion a year, with irrigation and drainage accounting for about US\$ 25 billion (Briscoe, 1999). Such figures have tended to decrease in more recent years, owing to a global shift from water resource development and supply to water resource and demand management (Perret, 2006). Saleth (2002) stresses that the cost of creating additional irrigation potential has become prohibitive in many countries. Public investment in irrigation is, however, still high since it also includes the massive rehabilitation works that are usually carried out prior to irrigation management transfer (IMT) (Vermillion and Sagardoy, 1999). Yet, the question as to the financial viability of such schemes remains, especially

* To whom all correspondence should be addressed.

욜 +27 12 420-5021; fax: +27 124204859 ;

e-mail:sylvain.perret@cirad.fr

Received 22 March 2006; accepted in revised form 27 September 2006. in view of the on-going IMT processes. Until recently, surface irrigation in developing countries classically fell under government-driven public works and rent-seeking operations (Briscoe, 1999), that systematically implied central public or parastatal management of operations. In many developing and transition countries, irrigation under public-sector management has long been characterised by poor technical, financial, and economic performance as well as the overall suboptimal use of irrigation facilities (Sampath, 1992). As a consequence, the degree of capital, operation, and maintenance cost recovery in developing countries remains far below the level required for financial autonomy (Briscoe, 1999).

Irrigation schemes worldwide are now faced with decentralisation and privatisation policies, aimed at increasing local participation and relieving Governments from the burden of financial and technical support (IWMI, 2003). During the past three decades, a large number of formerly State-owned and public sector managed schemes have been transferred to users (through the so-called Irrigation Management Transfer), who are now expected to bear at least the expenses incurred through operation and maintenance (O\&M) activities (Vermillion, 1997). In 2000, The Hague's World Water Vision clearly recommended that full-cost pricing be promoted and implemented (Cosgrove and 
Rijberman, 2000). Although it may prove feasible in developed environments, e.g. in Australia (Briscoe, 1999), full cost pricing may prove unrealistic in developing environments with subsistence-oriented smallholder irrigation schemes. This is why, while acknowledging that 'the recovery of full cost should be the goal for all water uses ...' the International Commission on Irrigation and Drainage (ICID) alternatively recommended that [in order to achieve sustainability, the full cost of water provision] 'need not necessarily be charged to the users' (Tardieu, 2005).

In subsistence irrigation agriculture, subsidisation by Government is usually justified by 'adjustments for societal objectives' (Rogers et al., 1998), e.g. food security objectives, multiplier effects of irrigation agriculture, positive impact on rural development, income redistribution, and other social benefits (Sampath, 1992; Briscoe, 1999; Jamin et al., 2005). Besides food self-sufficiency, achieving net profit over the long term is the motivating factor that sustains irrigated agriculture. Economically viable irrigation systems provide lifestyle and social options for farmers and also contribute to the wider economy and community. From the perspective of using water more economically, the great challenge in irrigated agriculture is to include the opportunity costs of irrigation water supply, which are often an order of magnitude higher than current charges (if any) (Briscoe, 1997).

Since both domestic and international financial resources are becoming increasingly difficult to obtain due to limited availability and competing needs, attention is increasingly being paid not only to the generation of financial resources to meet the O\&M expenses of existing projects, but also to the recovery of capital invested in the past in order to fund new projects or to rehabilitate old ones (Sampath, 1992).

\section{Investigating the full financial costs of irrigation in South Africa}

South Africa is a typical example of the situation described above and the changes in South African irrigation policy and management are no exception to those found in the rest of the world. During the apartheid era, following the recommendations of the Tomlinson Commission on the development of homeland areas (Union of South Africa, 1955), South Africa embarked on the development of irrigation schemes through public investment.

These government-initiated then publicly managed smallholder irrigation schemes have performed poorly (being 'mori- bund' according to Bembridge, 2000; or having 'collapsed' according to Backeberg, 2003). These schemes were neither financially viable nor self-sustaining since capital or operation costs were never covered by operation outputs and profit. Instead, under-pricing and government subsidisation of water infrastructure and services, and management by parastatal agencies generated dependency and ignorance on the farmers' side, since they were often reduced to functioning as workers on their own land (IWMI, 2003), ignoring the cost of infrastructure, the actual value of water as an input to production, and being unaware of its opportunity cost (Briscoe, 1997). After South Africa became a democracy in 1994, the Government withdrew from its previous policy of support and the above-mentioned schemes are now earmarked for revitalisation, rehabilitation, and ultimately the transfer of management to users. Moreover, users are now supposed to cover the financial costs (O\&M costs) of irrigation water and irrigation services internally, or initially at least in part (Backeberg, 2006). Capital cost recovery will be phased in gradually, in the form of a depreciation charge to farmers (see Box 1). Local management committees, then water user associations (WUAs), are supposed to take over the management of the technical and financial aspects of these schemes.

In spite of decentralisation and privatisation processes looming, public authorities are still committed to provide these schemes with a fresh start before management transfer and State withdrawal take place, in the form of revitalisation and rehabilitation programmes. The Government has been, and still is investing substantial amounts of public money in smallholder irrigation, with very low return, and at no real cost for private users as irrigators are hardly being charged at all (Perret, 2002; Denison and Manona, 2006a). The latter authors report that the Limpopo Provincial Department of Agriculture plans to spend R1.08bn. between 2006 and 2010 in rehabilitation of smallholder schemes. In the Eastern Cape, R100m. have been allocated in 2006 for the same purposes. Such investment represents a hidden subsidy to smallholder farming, mostly related to social objectives, food security, and rural development concerns, whereas the nation's overall liberalisation trend includes giving up subsidies to agriculture (Ortmann and Machethe, 2003).

In this context, the question as to what is the full financial cost of establishing or rehabilitating smallholder irrigation infrastructures seems legitimate and pertinent. The present paper addresses that question through the use of a methodology that has been developed and proposed by the International Com-

\section{Box 1}

Water pricing system for smallholder farmers (source: DWAF, 2002; Backeberg, 2003: 159-160; Backeberg, 2006: 4)

Following the National Water Act of 1998, the Department of Water Affairs and Forestry has refined a water pricing strategy. With regard to "emerging farmers" (i.e. smallholder irrigation farmers), the principles of the pricing system are as follows:

- In principle, the charges that are payable are (1) a water resource management charge (WRM), to the Catchment Management Agency (CMA), (2) O\&M charges, and (3) a depreciation charge;

- The WRM charge will be phased in over 5 years after the WUA is established; a minimum volume for use will be considered for charging (about $10000 \mathrm{~m}^{3}$ per annum); operational subsidies to CMA, and waiving of charges for limited periods may be considered;

- O\&M charges will be phased in over 5 years after the WUA is established; operational subsidies on O\&M costs will be phased out accordingly;

- A depreciation charge will be introduced in year 6 after the WUA is established, at a maximum of R0.01 per $\mathrm{m}^{3}$ par annum.

- WUAs may receive capital cost subsidies (in the form of construction or rehabilitation, or of grants - R10 000 per ha or R50 000 per member)

Such principles lie onto the prerequisite of prior full refurbishment of the schemes involved (in case they are not new ones), sponsored by the public sector (e.g. various ministries combining efforts). Besides, the first CMAs and WUAs are currently being established (2005). 
Figure 1

Supply financial cost, opportunity cost, and full economic cost for public irrigation (from Briscoe, 1997)

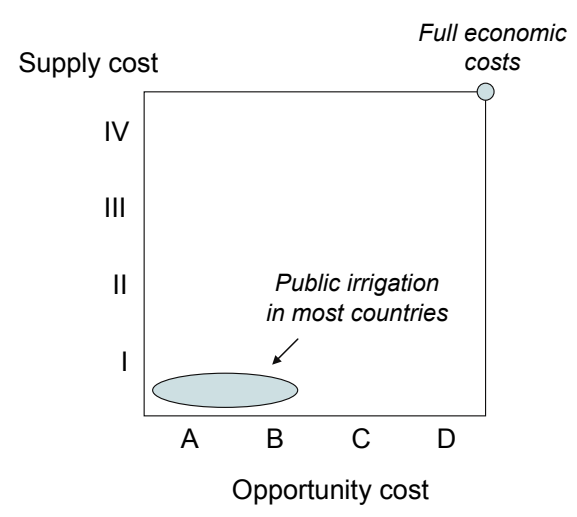

Legend:

Supply financial cost:

I Operation and Maintenance costs only

II Average financial costs (Capital + O\&M costs with capital valued in terms of historical costs

III Average financial costs, with capital costs computed in replacement terms

IV Long run marginal cost of additional supply

Opportunity cost:

A Water can be used only by an individual user

B Water can be leased or sold to neighbours

C Water can be leased or sold within a limited district or sector

D Water can be leased or sold to any users mission on Irrigation and Drainage (ICID) (Rieu and Gleyses, 2003). The paper critically discusses the applicability and implications of the proposed guidelines for assessing the costs of irrigation services in the case of smallholder irrigation in South Africa through a case study that is presented and discussed.

\section{The situation of smallholder irrigation in South Africa}

\section{Local perspectives}

Smallholder irrigation schemes (SIS) were mostly built during the 1950s and 1960s as a measure to achieve food security and economic crop production in the semi-arid areas of the homelands (Bantustans). Such schemes cover a total area of about 50000 ha (Denison and Manona, 2006b), while the total irrigation area in South Africa is about 1.3m. ha (Backeberg, 2003). About 180 of these schemes are located in the Limpopo Province of South Africa (Denison and Manona, 2006b). Their key features include a gravity-based supply system, a limited average farm size (about 1 to 2 ha per beneficiary), a marked subsistence orientation (maize being the major crop), and a significant area that is virtually never cropped (under tenure by non-farming occupiers) (Perret, 2002) (see case study scheme in Box 2). Nowadays, subsistence farming prevails in these schemes, with low productivity and virtually no commercialisation, as a result of decades of central management, lack of initiative or decisionmaking by the beneficiaries, lack of input, credit and produce markets, low land productivity, infrastructure degradation, massive male out-migration, unsuccessful financial management, and weakened land-related institutions (Bembridge, 2000; Perret, 2002; Backeberg, 2003; 2006).

\section{Policy and macro-perspectives}

Since 1994, the South African Government has undertaken massive reforms aimed at addressing rural poverty and inequalities inherited from the past regime. A new national water policy is in place (National Water Act of 1998), with its leading objective being equity, sustainability, representivity and efficiency.

An overall decentralisation process of water resource management is being implemented, and more specifically, an irrigation management transfer process is underway (Perret, 2002; Backeberg, 2003). Such processes suppose that, following a revitalisation phase (in the form of infrastructure rehabilitation, technical and managerial training, institutional and organisational facilitation), farmers will soon be in charge of their schemes, in institutional and financial terms. Each scheme is to be managed by a WUA, which will take charge of both water management, and cost recovery for water services (see Box 1). In other words, the WUA will achieve financial sustainability by selling water and water services to willing-to-pay farmers (Perret, 2002; Backeberg, 2006).

At macro-level, water scarcity is a critical issue in the country. Multiple users increasingly demand more water (e.g., for domestic, industrial, mining and power- generation purposes). Agriculture as a whole extracts about $60 \%$ of the resource while it directly contributes only about $4 \%$ of GDP (about $12 \%$ when including food and fibre processing) (Ortmann and Machethe, 2003). Furthermore, smallholder farming uses only $4 \%$ of all irrigation water, and is hardly commercialised (Perret, 2002).

\section{The meaning of water supply cost evaluation in smallholder irrigation}

In such a context, any investment and financial support by the public sector to smallholder irrigation schemes undoubtedly falls under the 'equity' objective of the National Water Act. Besides, any attempt to evaluate the full cost of supplying water to smallholder irrigation schemes may look suspect, being seen as a first step towards a comprehensive charging system for the poor. An 'opportunity cost' approach may allow for comparison with other sectors, and may ultimately challenge the idea of water supply to smallholder farming, for equity or social purposes, on the grounds of economic efficiency, and allocation to higher value use (Farolfi and Perret, 2002). This is why Rogers et al. (1998), Briscoe (1997), and Tardieu (2005) suggest considering costs, value and charges separately. According to Briscoe (1997) it is difficult and onerous to access information on the opportunity cost of irrigation water since figures vary dramatically in terms of place and season, and evaluation methods are not universally accepted.

The methodological framework proposed by ICID (Rieu and Gleyses, 2003) and tested here does not address the opportunity cost of irrigation water per se, but rather considers the opportunity cost of investment in irrigation (as the return forgone by not investing in an alternative use).

\section{Conceptual frameworks}

\section{Different costs incurred by irrigation}

A comprehensive definition of costs is given by Bouma et al. (2001): costs represent the value forgone in producing a good or service. Briscoe (1997) and then Rogers et al. (1998) outlined the theoretical underpinnings of the idea of 'water as an economic good', and suggested a conceptual framework for identifying both direct costs (supply financial costs) and indirect costs (opportunity costs, costs of externalities) (Fig. 1).

As shown in Fig. 1, public irrigation usually covers only internal O\&M costs, at best, while capital costs and opportunity 
costs are ignored. Irrigated agriculture may generate externalities such as soil salinisation, non-point source pollution with fertilisers, water pollution with pesticides, losses of aquatic habitat, lowering of the water table, and the like. The cost of mitigating these and other externalities resulting from public irrigation are usually equally ignored. Briscoe (1997) suggests that such costs be incorporated in increasing the supply costs, while Rieu and Gleyses (2003) warn against double counting, since some mitigation costs may be internalised in the irrigation systems themselves. Besides, externalities may be positive, especially in the form of return flows from irrigation. Finally, Tardieu (2005) considers resource costs, which are not internalised. Resource costs are accounted for in the water pricing strategy of South Africa in the form of a water resource management charge (see Box 1).

Regarding the evaluation of financial costs, an 'opportunity cost $^{\star}$ approach (i.e. considering the return that could be made from an alternative use of the capital invested) may not be relevant since past and current investments into smallholder irrigation schemes in South Africa were aligned with social and equity concerns, rather than with economic performance concerns.

The following list displays the different costs for irrigation water, which form the full economic cost of water (Rogers et al., 1998), and exclude environmental externalities.

- Operation and maintenance $(O \& M)$ costs: These are associated with the daily running of the supply system (e.g. electricity for pumping, labour, repair materials, input costs for managing and operating storage and distribution); they often include administrative and other direct costs (e.g. internalised environmental and resource costs); in practice, there is usually little dispute as to what are considered O\&M costs and how they can be measured.

- Capital costs: These costs should include capital consumption (depreciation charges) and interest costs associated with infrastructure, reservoirs and distribution systems; the ICID guidelines on full financial costs stress a forward-looking accounting stance and look for the costs associated with replacement of the capital stock with increasing marginal costs supplies.

- Opportunity costs: These address the fact that by consuming water, the user is depriving another user of the water; if that other user has a higher value for the water, then there are some opportunity costs experienced by society due to this misallocation of the resource.

- Economic externalities: These include the positive or negative impacts of irrigation use upon other activities (e.g. pollution, salinisation, upstream diversion, downstream recharge).

The first two costs form the direct full financial costs. Tardieu and Prefol (2002) suggest that these two be covered for sustainability purposes. They form the so-called 'sustainability costs', which recovery ensures the scheme's operation, at least in the short- and medium term, and is acceptable by users (if charged).

This paper focuses on these direct financial costs. It exploits a methodology that has been developed and proposed by a working group of the International Commission on Irrigation and Drainage (Rieu and Gleyses, 2003), as is shown below. The present paper will show that evaluating O\&M and capital costs is not necessarily that straightforward, as is illustrated when looking at some specific traits of smallholder irrigation in South Africa, and requires some adaptation.

\section{Evaluating full financial costs: The ICID proposal}

During its conference in Cape Town in 2000, ICID tasked its Working Group on Socio-Economic Impacts and Policy Issues to establish guidelines for water policy, notably on the assessment of existing and future costs of irrigation services. Rieu and Gleyses (2003) have drawn from that working group, and from previous work (especially Rogers et al., 1998), and have come up with a methodology (guidelines, forming a set of methods), supported by spreadsheets. The proposed methodology, presented at the ICID Conference in Montpellier, France, in 2003 (Rieu and Gleyses, 2003), focuses on two features that are specific to water supply schemes:

- They consist of assets with varying lengths in working service life, often beyond the terms of the loans contracted to finance them

- Subsequent maintenance costs grow over time and are difficult to foresee

Methodological options are suggested for both points. The costing model relies on basic economics, including financial evaluation techniques, and the discounting principle. Its final objectives are to assess the total effect of irrigation water management on welfare, and to allow for the comparison of costs between various settings, schemes and countries (Rieu and Gleyses, 2003).

The framework focuses on direct financial costs to economic agents, leaving second-order effects on employment, prices, and competitiveness out of the analysis. This means that the estimation of the contribution to welfare does not address its distribution among stakeholders. Although a useful complement to the economic approach, such a social approach is not addressed in the proposed approach.

The ICID guidelines define several key notions. For instance, the water supply system is clearly delineated, from the abstraction point to the irrigation hydrant; it includes abstraction and storage infrastructures, conveyance equipment, collective pumping and filtration facilities (if any).

\section{Assessing costs: Critical analysis of the proposed ICID guidelines}

\section{Necessary data and assumptions of the proposed guidelines}

According to the ICID guidelines for evaluating the full economic costs of irrigation, presented by Rieu and Gleyses (2003), the following data and information are necessary to perform the calculations:

- The so-called Public Works Index, which takes account of inflation, and allows for evaluating the current value of assets. Such an index is generally available in European countries, but not in most developing countries.

- The discount rate, which according to the suggestion made in the proposed ICID guidelines, should be equal to the borrowing rate, excluding inflation (taking into account WUA practices in Europe)

- The service life or working life, which allows for the estimation of the average annual cost of capital. This type of data may vary dramatically depending on the type of asset, service and use conditions, etc. The service life is usually long, with life spans of up to 20 or even 50 years in the case of irrigation infrastructures. European values and standards were used for the guidelines, while developing tropical values and standards may show very different characteristics as is discussed further on in this paper. 
- Depreciation is an important concept in the long-term management of assets, since it addresses the issue of asset replacements (at the end of the service life). The most appropriate method of determining annual depreciation can be seen to be the 'utilisation method', whereby depreciation is calculated according to the usage of the asset (the more the asset is used, the quicker it loses its value). The evaluation of annual depreciation does, however, sometimes prove to be difficult, as was the case in this study where information was not available regarding the annual usage of assets. As a result the straight-line method was used in line with the ICID guidelines, which suggest the use of linear depreciation along the service life (cost/service life).

\section{Issues pertaining to capital cost evaluation}

With regard to capital costs, the lack of basic information is one of the major issues. Most smallholder schemes in former homelands, as described in previous sections, were built long ago (1950s to 60s), and most records and archives were lost after the former parastatals (managing government corporations) in charge of the schemes' construction and management were dismantled at the end of the apartheid era (early 1990s).

In the absence of any list, map, or blueprint of infrastructures, a detailed on-site description of the existing infrastructures is often the inescapable prerequisite to any further analysis. Studies currently carried out by consulting companies do not help much as they may describe and mix up genuine, untouched infrastructures with infrastructures that have been refurbished at some stage along the line, as well as new infrastructures or systems that have replaced others (modernisation) (Denison and Manona, 2006).

The ICID guidelines only consider items related to irrigation water supply (with the notable exceptions of roads and engineering fees). The organisation responsible for the overall management of the scheme (management of building, fencing, and equipment such as furniture, communication equipment, etc.) may incur other minor capital costs, which are more likely to be shouldered by the WUA itself, than other irrigation capital costs. This is important because under the proposed financing of irrigation in South Africa, the government will be responsible for the overall management of the scheme, while the WUAs will be responsible for the operational and maintenance costs.

The purpose of certain items may have changed over time. Some items that were initially dedicated to irrigation water supply (e.g. Casteel Dam in Dingleydale -see Box 2) have now been allocated a broader function of supplying domestic water also to neighbouring communities. Conversely, infrastructural items might not have been involved initially in irrigation water supply, and became involved later, in line with the development of an irrigation scheme (e.g. the case of the main canal at Boschkloof, Limpopo Province, which was initially meant for domestic water supply, but is now supplying an irrigation scheme). Hence there is a need to consider sharing the average capital cost incurred between different users from some point along the history of the item(s). More difficult to address is the common and informal 'multiple use' of irrigation infrastructure in developing countries (Van Koppen et al., 2006). This may include informal diversions and uses, such as those for agricultural (e.g. livestock watering and fish culture) or domestic purposes and small enterprises (e.g. brick-making and beer-brewing).

With regard to the ICID guidelines proposed by Rieu and Gleyses (2003), basic questions remain unanswered, e.g. which 'year of construction' is to be applied when it comes to items that have been partially refurbished? How should items that have acquired new purposes over time, or that are informally shared by different uses and users, be considered? Should a cost-sharing approach be followed? Is an 'opportunity cost'-based approach still relevant when the purpose of certain items may have evolved along their service life? To what extent do the suggested standards in terms of service life apply in tropical, gravity-based and developing conditions (items are quite specific to such conditions, with no standard whatsoever)? Which discount rate should be chosen? (the social and financial discount rates have varied dramatically in South Africa during the last 40 years, broadly between 3 and $20 \%$, yet showing a general tendency to decline and stabilise around 3 to $6 \%$ since the $1980 \mathrm{~s}$ ).

\section{Issues pertaining to maintenance cost evaluation}

Yet again, the lack of records, maps, and archives hampers efforts on the evaluation of maintenance costs, especially when a

\section{Box 2 \\ Issues pertaining to infrastructures and capital costs in Dingleydale - New Forest (Limpopo Province, South Africa)}

(Source: Perret \& Touchain, 2002 and own survey)

The scheme was built in 1965. It covers about 1600 ha, with about 1400 beneficiaries. While the Agricultural and Rural Development Corporation (ARDC, a parastatal management agency) was managing the scheme, farmers were never supposed to pay for costs incurred by water supply. From 1996 onwards, ARDC collapsed and withdrew from any form of support to the farmers; the scheme has been left moribund, with few productive activities happening. Currently only about 700 ha are being irrigated with cropping patterns, mostly extensive and little productive, and benefiting about 900 farmers.

In 2000, the scheme has been included as a pilot, being part of an ambitious revitalisation program by the Provincial Department of Agriculture (Limpopo). At that stage, consultancy companies had to establish lists of infrastructures in order to identify and budget the needs for refurbishment, since there was little information available.

When it came to evaluate the capital costs incurred by water supply (limited to a depreciation approach, with regard to self-management by farmers), the research team involved had to apply the 2000 value of the items listed, knowing that certain items had been well refurbished. Some few sections of canals, or weirs were rebuilt as new, while other items have just been abandoned (former "tobacco project" area, turned into a grazing area), while others had been left as is (e.g. dams), hence a huge heterogeneity and some confusion from the initial situation (Perret and Touchain, 2002) (see list of items in Table 1).

The establishment of management committees in the two main sections of the scheme does not imply the setup of any full cost recovery system in the short term (see Box 1). As to capital costs, there is no repayment of loan involved since the initial funding of infrastructures was considered sunk costs by the public sector. Also, recent refurbishment works have been shouldered by the public sector with no expected repayment or cost recovery, and probably with little expectation in term of economic impact or return. 
'discounted' average annual maintenance cost is targeted. The list of assets and discounted values used to determine capital costs has to be used here. Still, it may be quite difficult to evaluate the requirements in terms of percentage of the discounted investment to be allocated to maintenance annually. References and standards are lacking in gravity-based, developing, and tropical situations where floods, trampling of livestock, bad quality of cement, vegetation invasion, soil erosion, silting, and the like, may require more attention, and hence more maintenance, than in western conditions.

Based on experiences in South Africa, it can also be shown that evaluating maintenance costs may be complicated if certain prevailing practices, that imply no financial transaction, have to be considered (e.g. manual cleaning/clearing out of canals by farmers themselves). The maintenance issue becomes crucial since WUAs will have to cover these costs, via a monetary and/ or labour-based contribution by farmers, especially in view of the past tendency to curtail such contributions.

The simple fact that different entities may ultimately cover capital costs on the one hand (the public sector), and O\&M costs on the other hand (mostly the farmers through the WUA, possibly other users) generates some complication with regard to the proposed model. These entities obviously have different preferences and perspectives with regard to the opportunity cost of capital and as a result different discount rates may be used.

\section{Issues pertaining to operational cost evaluation}

Sound data recording and bookkeeping for O\&M is of crucial importance in irrigation (Tiercelin, 1998). It makes the evaluation of direct operational costs easy. In South Africa, such a system still has to be put in place for each WUA. In the meantime, experts and local stakeholders can provide prospective information with regard to operational costs that will potentially be incurred. It must be emphasised here that gravity-based systems do not incur much variable operational costs (e.g. no pumping involved), but that the costs that are incurred are important as they will be the first to be charged to the farmers, along with maintenance costs, according to a phasing in process (see Box 2).

Still, calculating the 'discounted' average annual operational cost requires all the prerequisites and assumptions mentioned earlier on and raises issues regarding the choice of discount rate, of the multi-purpose nature of certain items, etc., as mentioned earlier on.

\section{A case study in Dingleydale-New Forest: Evalu- ating capital costs}

Perret and Touchain (2002) listed all the irrigation-related assets and infrastructures in Dingleydale-New Forest (see Box 2). The current value (year 2000) of these assets was established, along with information such as service life and date of construction. This information was mobilised in order to meet the proposed guidelines and establish the annual total financial costs for a period from 1965 (construction) to 2000 (refurbishment and value assessment). The idea was to use that case study to investigate the applicability of the guidelines in developing tropical, smallholder irrigation conditions.

The model required the initial investment costs and maintenance/replacement costs of the irrigation scheme from construction to 2000. Since evaluation was based on figures obtained in 2000 , the costs had to be discounted back to 1965, the year of construction. Similar regression is possible in Europe by means of a Civil Engineering Index (CEI) (Rieu and Gleyses, 2003). In South Africa, such a CEI was calculated only until 1970. Alternative indexes or discount rates were therefore needed to fully determine the initial investment costs and maintenance/replacement costs.

In irrigation schemes and many other agricultural projects, initial capital expenditure leads up to a steady state of increased production after several years. Cash-flow discounting is a way of setting initial capital expenditure against future benefits or, more generally, of balancing costs incurred and benefits received at different periods in the future.

\section{Initial assumptions and choices}

Various assumptions and choices were made in the development of the model, since limited information was available. The first set of necessary choices refers to the relevant cash flow. In order to evaluate the project, the possibility of whether or not changes in cash flows add value to the firm (here, an irrigation scheme) must be considered. The first step is to identify the cash flows that are relevant to the decision. Relevant cash flows are those that result in changes in or increments to the firm's existing cash flow and are called the incremental cash flows associated with the project. In the capital budgeting process, the after-tax incremental tax flows are of interest, but given the nature of the project (government-funded), taxes were ignored since government does not pay any taxes. In determining the relevant cash flow another choice was to ignore opportunity costs. It was assumed that the farmers had not given up any existing benefit from usage of the land prior to the irrigation scheme. Changes to net working capital have been further ignored since the crops farmed on the land were seasonal in nature and working capital completed a full cycle within a year.

Assumptions were further necessary regarding inflation. Inflation affects the value of a capital investment project by changing the nominal values of the cash flows over the life of the project. There are two key principles when dealing with inflation in capital budgeting. Firstly, inflation must be treated consistently when calculating both the cash flows and the discount rate. Secondly, the choice of doing the calculation on either a real or nominal basis depends on the sources of inflation facing the cash flows of the project. It is very important that inflation is treated consistently across the entire valuation exercise. The gauge of expected inflation included in these measures is the Consumer Price Index (CPI) (Firer et al., 2003). If, however, some of the sources of inflation facing the project's cash flows are not CPI related, then alternative indexes must be used.

Assumptions on the discount rate were also made. The general principle guiding the choice of the discount rate is that it represents the expected rate of return required by the providers of the capital used to fund the project. Thus, it should be a weighted average of all the firm's sources of capital, and it should reflect the specific risks of the project's expected cash flows. The investment's weighted average cost of capital (WACC) (consisting of both the cost of debt and the cost of equity) can be used for identifying a project discount rate. Since no equity was contributed to the investment, the cost of debt was the only WACC component. The cost of debt of an investment can be easily established by observing the current yield to maturity (YTM) of its debt instruments if they are publicly traded, or by using the lending rate obtained from banks.

Since it was a project funded by government, no lending rates could be used. It was necessary for this study to determine an appropriate instrument on which to base a lending rate. The 


\begin{tabular}{|c|c|c|c|c|c|}
\hline \multicolumn{6}{|c|}{$\begin{array}{l}\text { TABLE 1 } \\
\text { List of infrastructures involved in irrigation water supply and related management } \\
\text { requirements in Dingleydale-New Forest (values based on initial investment year) }\end{array}$} \\
\hline \multirow[b]{2}{*}{ Item } & \multirow[b]{2}{*}{ Cost in 2000} & \multicolumn{4}{|c|}{ Initial investment value in 1965 based on: } \\
\hline & & CPI-values & $\begin{array}{l}\text { Farming requisites } \\
\text { index }\end{array}$ & Civil eng & ndex \\
\hline Main canal - concrete - DD & R 25426800 & R 856883 & R 549769 & $\mathrm{R}$ & 339706 \\
\hline Main canal - concrete - NF & R 20206400 & R 680956 & R 436895 & $\mathrm{R}$ & 269960 \\
\hline Secondary canal - concrete - DD & R 43260000 & R 1457862 & R 935351 & $\mathrm{R}$ & 577960 \\
\hline Secondary canal - concrete - NF & R 16532000 & $\mathrm{R} \quad 557128$ & R 357449 & $\mathrm{R}$ & 220870 \\
\hline Balancing dam & 510000 & 17187 & $\mathrm{R} \quad 11027$ & $\mathrm{R}$ & 6814 \\
\hline Main dam & R 9000000 & $\mathrm{R} \quad 303300$ & R 194595 & $\mathrm{R}$ & 120241 \\
\hline Flow measuring device & 90000 & 3033 & 1946 & $\mathrm{R}$ & 1202 \\
\hline Secondary pipe - concrete & R 10867250 & R 366226 & R 234968 & $\mathrm{R}$ & 145188 \\
\hline Silt trap & 200000 & 6740 & 4324 & $\mathrm{R}$ & 2672 \\
\hline Large syphon & R 3150000 & $\begin{array}{ll}\mathrm{R} & 106155 \\
\end{array}$ & $\begin{array}{llll}\mathrm{R} & 68 & 108 \\
\end{array}$ & $\mathrm{R}$ & 42084 \\
\hline Small syphon & R 5760000 & R 194112 & R 124541 & $\mathrm{R}$ & 76954 \\
\hline Main weir & $\mathrm{R} \quad 2000000$ & 67400 & R 43243 & $\mathrm{R}$ & 26720 \\
\hline Secondary weir & 195000 & 6572 & 4216 & $\mathrm{R}$ & 2605 \\
\hline Building & 20000 & 674 & 432 & $\mathrm{R}$ & 267 \\
\hline Drinking trough & 80000 & 2696 & 1730 & $\mathrm{R}$ & 1069 \\
\hline Fence & $\mathrm{R} \quad 2250000$ & 75825 & R 48649 & $\mathrm{R}$ & 30060 \\
\hline Gravel road & R 2400000 & 80880 & 92 & $\mathrm{R}$ & 32064 \\
\hline Road crossing & 675000 & 22748 & $\mathrm{R} \quad 14595$ & $\mathrm{R}$ & 9018 \\
\hline Storm crossing & 440000 & 14828 & 9514 & $\mathrm{R}$ & 5878 \\
\hline Washing area & 60000 & 2022 & 1297 & $\mathrm{R}$ & 802 \\
\hline Total initial investment value & R 143122450 & R 4823227 & R3 094539 & $\mathrm{R}$ & 1912137 \\
\hline
\end{tabular}

(Source Perret \& Touchain,, 2002, and own calculations)

most tradable instruments are treasury bills (T-bills), bankers' acceptances, Land Bank bills and promissory notes, prescribed asset bills and negotiable certificates of deposit (NCDs). Studies elsewhere in the world (for example, Ibbotson and Sinquefield, 1989) routinely use the T-bill as providing the benchmark for 'risk-free' returns. Morgenrood (1987; 1988a;b), in a series of articles on the history of the T-bill in South Africa between 1881 and 1981, concluded that during the first 100 years of its existence the T-bill failed to come into its own as a benchmark for the risk-free rate. This author ascribes this to the enduring official reluctance to refrain from intervening in the financial markets. The De Kock Commission of Enquiry (Mohr, 1985) found that the South African Treasury Bill market was neither free nor competitive, and therefore failed to produce realistic, market-related interest rates. Major distortions in short-term interest rates have been caused by the lack of supply of liquid assets from time to time, especially during the 1970s (Mohr, 1985). This resulted in an artificial demand for such assets in order to comply with the liquid asset requirements, resulting in their prices being higher. Thus, wide differentials between the rates on liquid assets, such as T-bills, and those on nonliquid assets, such as NCDs, existed (Firer et al., 2003). The NCD rates have, on the other hand, not been distorted by the various investment requirements applying to banks, building societies, insurers and pension funds (as was the case with the other available instruments) and NCD rates can therefore be regarded as representing the true cost of money (Firer et al., 2003) as well as a better basis to use in determining the riskfree rate of investment. Faced with limited information availability (e.g. only construction cost for 2000 was available), the model exploited various alternatives, and followed several methodological steps, as follows:

\section{Determining the initial value of the irrigation scheme (1965)}

As no specific escalation index is available for the irrigation industry to be used in determining the value of the irrigation scheme in 1965, three different indexes namely the CPI, the farming requisites index and the civil engineering index were used to determine the initial value of the irrigation scheme. This was to ensure that some of the sources of inflation facing the project's cash flows are not CPI related as, for example, a key input such as a measuring flow device, is imported and its price (in rand) depends on international inflation and the rand depreciation, in which case another index might be more appropriate. Using three different indexes ensures that the best available measures of price inflation are used to calculate the true initial cost of the irrigation scheme.

Table 1 provides a list of infrastructures involved in irrigation water supply and related management requirements in Dingleydale-New Forest (Perret and Touchain, 2002), which are discounted back to 1965 (initial investment year) using the three different indexes.

\section{Evaluating annual maintenance costs}

Inflation affects the value of a capital investment project by changing the nominal values of the cash flows over the life of the project. There are two key principles when dealing with infla- 


\begin{tabular}{|l|c|c|}
\hline \multicolumn{3}{|c|}{ TABLE 2 } \\
$\begin{array}{c}\text { Maintenance cost per item as allocated by mainte- } \\
\text { nance rate (source: Perret \& Touchain, 2002; } \\
\text { Tiercelin, 1998) (Base year: 1965) }\end{array}$ \\
\hline Item & $\begin{array}{c}\text { Annual } \\
\text { mainte- } \\
\text { nance \% }\end{array}$ & $\begin{array}{c}\text { Replace- } \\
\text { ment year }\end{array}$ \\
\hline Main canal - concrete - DD & 0.5 & 2010 \\
\hline Main canal - concrete - NF & 0.5 & 2010 \\
\hline Secondary canal - concrete - DD & 0.5 & 2010 \\
\hline Secondary canal - concrete - NF & 0.5 & 2010 \\
\hline Balancing dam & 1.5 & 2010 \\
\hline Main dam & 0.2 & 2025 \\
\hline Flow measuring device & 0.5 & 1995 \\
\hline Secondary pipe - concrete & 0.1 & 2025 \\
\hline Silt trap & 5 & 2010 \\
\hline Large syphon & 0.1 & 2025 \\
\hline Small syphon & 0.1 & 2025 \\
\hline Main weir & 0.2 & 2010 \\
\hline Secondary weir & 0.2 & 2010 \\
\hline Building & 1 & 2025 \\
\hline Drinking trough & 0.5 & 1990 \\
\hline Fence & 1 & 2015 \\
\hline Gravel road & 5 & 2065 \\
\hline Road crossing & 0.5 & 2010 \\
\hline Storm crossing & 0.5 & 2010 \\
\hline Washing area & 0.5 & 1990 \\
\hline
\end{tabular}

tion in capital budgeting. Firstly, inflation must be treated consistently when calculating both the cash flows and the discount rate. Secondly, deciding on nominal or real terms depends on the sources of inflation facing the cash flows of the project. Both the risk-free rate observed in the bond market and the cost of debt represent nominal rates, i.e. rates that include the effects of expected inflation over the life of the bond. Annual maintenance costs have been adjusted in order to take effect of inflation into consideration, using the following equation:

$$
\mathrm{CF}=\mathrm{CF}(1+\mathrm{inf})^{\mathrm{n}}
$$

where:

$$
\begin{aligned}
& \mathrm{CF}=\text { cash flow } \\
& \text { inf }=\text { inflation rate } \\
& \mathrm{n}=\text { number of years }
\end{aligned}
$$

The gauge of expected inflation included in these measures is the CPI. Table 2 provides the maintenance rate per item.

Since three different indexes were used to determine the initial investment value, three different maintenance values will be used under each scenario although annual maintenance will be calculated by adjusting for inflation by using the CPI Index. Table 3 provides the total annual maintenance cost under each initial investment assumption.

Table 4 shows the annual net cash flow values (NCFs) under each scenario.

\section{Determining the net present value (NPV) of the annual cash flows}

In finance, the discounted cash flow model operates as the basic framework for most analyses. The conventional view is that the net present value of a project is the measure of the value that it will add to the firm undertaking it. Thus, investing in a positive (negative) net present value project will increase (decrease) the overall value of the firm. The net present value (NPV) of the annual cash flows has been determined over the 35-year period by using the following formula for NPV:

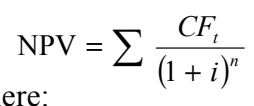

$\mathrm{i}=$ discount rate

An efficient allocation of scarce capital resources requires that they be priced at the 'marginal opportunity cost of capital,' or, in other words, the social cost of capital to the country. Since the marginal opportunity cost of capital is a theoretical concept, it is necessary to approximate this value. Although Firer et al. (2003) suggested using the NCDs as applicable discount rate, it was decided to use the average return on the long-term government stock index (12\%), the 75-year (1925 to 1999) average return on government bonds $(7.4 \%)$ and the 75 -year average yield on negotiable certificates of deposit (NCD) $(6.5 \%)$ to broaden the various alternatives available to our model. It was decided to desist from using a single discount rate since South Africa's economic conditions changed dramatically between 1965 and 1990 (from an era of enforced apartheid to an era where apartheid was abolished). It may be argued that the different rates used are too high because some agricultural projects in South Africa used a discount rate of $5 \%$, and that this lower rate was also used to calculate the pension payment to members of the AIP fund in 1995 (Hoskins and Du Preez, 2004). Table 5 gives the NPV under each alternative scenario and under each alternative discount rate.

All the net present values of the capital investment calculated under the various methods are negative. This is due to the fact that only the costs were taken into consideration, since the intention was to calculate how much farmers should pay for the irrigation scheme if it were not government funded. The next step in the analysis is to estimate the annual contribution from users of the irrigation scheme, if they had to pay for the opportunity.

\section{Determining the annual contribution to settle the loan on the irrigation scheme}

This was done by:

$$
\mathrm{PV}=P M T\left[\frac{1+(1+i)^{-n}}{i}\right]
$$

where:

$\mathrm{PV}=$ present value (the various NPVs calculated above)

PMT = annual payment

$\mathrm{i}=$ discount rate

We used the same assumptions as before to determine the applicable discount rate.

Table 6 provides the total annual payment under each scenario and under each discount rate.

It is clear from this table that the total annual payments for the irrigation scheme under all the various assumptions are high. The cost per hectare for the 700 ha irrigation scheme varies from R207.19 to R601.11 under the various assumptions. Perret and Touchain (2002) found that maize yields were ranging from about $1 \mathrm{t} /$ ha to about $7 \mathrm{t} / \mathrm{ha}$ for the few most intensive farmers. The average yield for dry maize, however, was about $2 \mathrm{t} / \mathrm{ha}$. Considering this figure, and a net farm gate price of 


\begin{tabular}{|c|c|c|c|c|c|c|c|c|c|}
\hline \multicolumn{10}{|c|}{$\begin{array}{c}\text { TABLE } 3 \\
\begin{array}{c}\text { Total yearly maintenance cost and replacement cost under each initial } \\
\text { investment assumption (base year: 1965) }\end{array}\end{array}$} \\
\hline & \multicolumn{3}{|c|}{ CPI-values } & \multicolumn{3}{|c|}{ Farming req index } & \multicolumn{3}{|c|}{ Civil engineering index } \\
\hline & \multicolumn{2}{|c|}{$\begin{array}{l}\text { Maintenance } \\
\text { cost }\end{array}$} & $\begin{array}{l}\text { Replacement } \\
\text { cost }\end{array}$ & \multicolumn{2}{|c|}{$\begin{array}{l}\text { Maintenance } \\
\text { cost }\end{array}$} & $\begin{array}{l}\text { Replacement } \\
\text { cost }\end{array}$ & \multicolumn{2}{|c|}{$\begin{array}{l}\text { Maintenance } \\
\text { cost }\end{array}$} & $\begin{array}{l}\text { Replacement } \\
\text { cost }\end{array}$ \\
\hline 1965 & $\mathrm{R}$ & 24816 & & & 15921 & & & 9838 & \\
\hline 1966 & $\mathrm{R}$ & 25682 & & & 16477 & & & 10181 & \\
\hline 1967 & $\mathrm{R}$ & 25711 & & & 16496 & & & 10193 & \\
\hline 1968 & $\mathrm{R}$ & 25729 & & & 16507 & & $\mathrm{R}$ & 10200 & \\
\hline 1969 & $\mathrm{R}$ & 25759 & & $\mathrm{R}$ & 16526 & & & 10212 & \\
\hline 1970 & $\mathrm{R}$ & 25796 & & & 16550 & & $\mathrm{R}$ & 10227 & \\
\hline 1971 & $\mathrm{R}$ & 25853 & & & 16587 & & $\mathrm{R}$ & 10249 & \\
\hline 1972 & $\mathrm{R}$ & 25920 & & & 16630 & & $\mathrm{R}$ & 10276 & \\
\hline 1973 & $\mathrm{R}$ & 26027 & & $\mathrm{R}$ & 16698 & & $\mathrm{R}$ & 10318 & \\
\hline 1974 & $\mathrm{R}$ & 26166 & & & 16788 & & & 10373 & \\
\hline 1975 & $\mathrm{R}$ & 26337 & & $\mathrm{R}$ & 16897 & & $\mathrm{R}$ & 10441 & \\
\hline 1976 & $\mathrm{R}$ & 26503 & & & 17004 & & & 10507 & \\
\hline 1977 & $\mathrm{R}$ & 26692 & & & 17125 & & $\mathrm{R}$ & 10582 & \\
\hline 1978 & & 26900 & & & 17259 & & & 10664 & \\
\hline 1979 & $\mathrm{R}$ & 27178 & & $\mathrm{R}$ & 17437 & & $\mathrm{R}$ & 10775 & \\
\hline 1980 & & 27501 & & & 17644 & & $\mathrm{R}$ & 10902 & \\
\hline 1981 & $\mathrm{R}$ & 27910 & & $\mathrm{R}$ & 17907 & & $\mathrm{R}$ & 11065 & \\
\hline 1982 & $\mathrm{R}$ & 28362 & & & 18197 & & $\mathrm{R}$ & 11244 & \\
\hline 1983 & & 28799 & & & 18477 & & $\mathrm{R}$ & 11417 & \\
\hline 1984 & & 29258 & & & 18771 & & & 11599 & \\
\hline 1985 & $\mathrm{R}$ & 29982 & & & 19236 & & $\mathrm{R}$ & 11886 & \\
\hline 1986 & & 30945 & & & 19854 & & $\mathrm{R}$ & 12268 & \\
\hline 1987 & $\mathrm{R}$ & 31935 & & & 20489 & & $\mathrm{R}$ & 12661 & \\
\hline 1988 & & 32846 & & $\mathrm{R}$ & 21074 & & $\mathrm{R}$ & 13022 & \\
\hline 1989 & $\mathrm{R}$ & 34030 & & $\mathrm{R}$ & 21833 & & $\mathrm{R}$ & 13491 & \\
\hline 1990 & & 35347 & R 59416 & & 22679 & R 59878 & $\mathrm{R}$ & 14013 & R 67165 \\
\hline 1991 & $\mathrm{R}$ & 36963 & & & 23715 & & $\mathrm{R}$ & 14654 & \\
\hline 1992 & & 38648 & & & 24796 & & $\mathrm{R}$ & 15322 & \\
\hline 1993 & $\mathrm{R}$ & 39993 & & & 25659 & & $\mathrm{R}$ & 15855 & \\
\hline 1994 & & 41350 & & $\mathrm{R}$ & 26530 & & $\mathrm{R}$ & 16393 & \\
\hline 1995 & & 42785 & $\begin{array}{|lll|}\mathrm{R} & 65169 \\
\end{array}$ & & 27450 & $\begin{array}{ll}\text { R } & 60811\end{array}$ & $\mathrm{R}$ & 16962 & \begin{tabular}{|lll}
$\mathrm{R}$ & 63075 \\
\end{tabular} \\
\hline 1996 & $\mathrm{R}$ & 44105 & & & 28297 & & $\mathrm{R}$ & 17485 & \\
\hline 1997 & & 45765 & & & 29362 & & $\mathrm{R}$ & 18143 & \\
\hline 1998 & $\mathrm{R}$ & 47204 & & & 30286 & & $\mathrm{R}$ & 18714 & \\
\hline 1999 & $\mathrm{R}$ & 48366 & & & 31031 & & $\mathrm{R}$ & 19174 & \\
\hline 2000 & $\mathrm{R}$ & 49624 & & $\mathrm{R}$ & 31838 & & $\mathrm{R}$ & 19673 & \\
\hline
\end{tabular}

R800/t during 2000, the cost of irrigation per hectare represents between $13 \%$ and $37.5 \%$ of total income, which seems far beyond what farmers will be willing to or are able to pay. In other irrigation schemes, Backeberg (2006) confirms that willingness to pay by smallholder farmers is not sufficient to cover the costs of water services.

\section{Conclusion}

This paper assessed the applicability of the existing ICID guidelines for evaluating the full financial costs of irrigation in developing conditions, based on its application in a South African case study. The analysis demonstrates that an application of the ICID guidelines in a tropical developing context is feasible, but that they need to be adapted as they are based on western standards. Such adaptations refer to the identification of the discount rate, the calculation of the current value as well as the estimation of the service life of infrastructure and equipment. In this paper several scenarios were outlined and tested in order to identify an appropriate surrogate discount rate. The average yield on Negotiable Certificates of Deposit (NCD) is suggested as a surrogate for treasury bills and hence as a substitute for the discount rate. Aside from the choice of proper parameters, the application may prove difficult owing to specific traits of irrigation infrastructure in developing environments. The evolving purpose of certain items over time, the widespread, informal and multiple side uses of irrigation water and infrastructure by neighbouring communities, the lack of basic information, records, water measuring systems, the lack of established standards on the service life of equipment and infrastructure under harsh tropical and developing conditions constitute, are all factors that hinder straightforward and accurate calculations of capital and O\&M costs. 


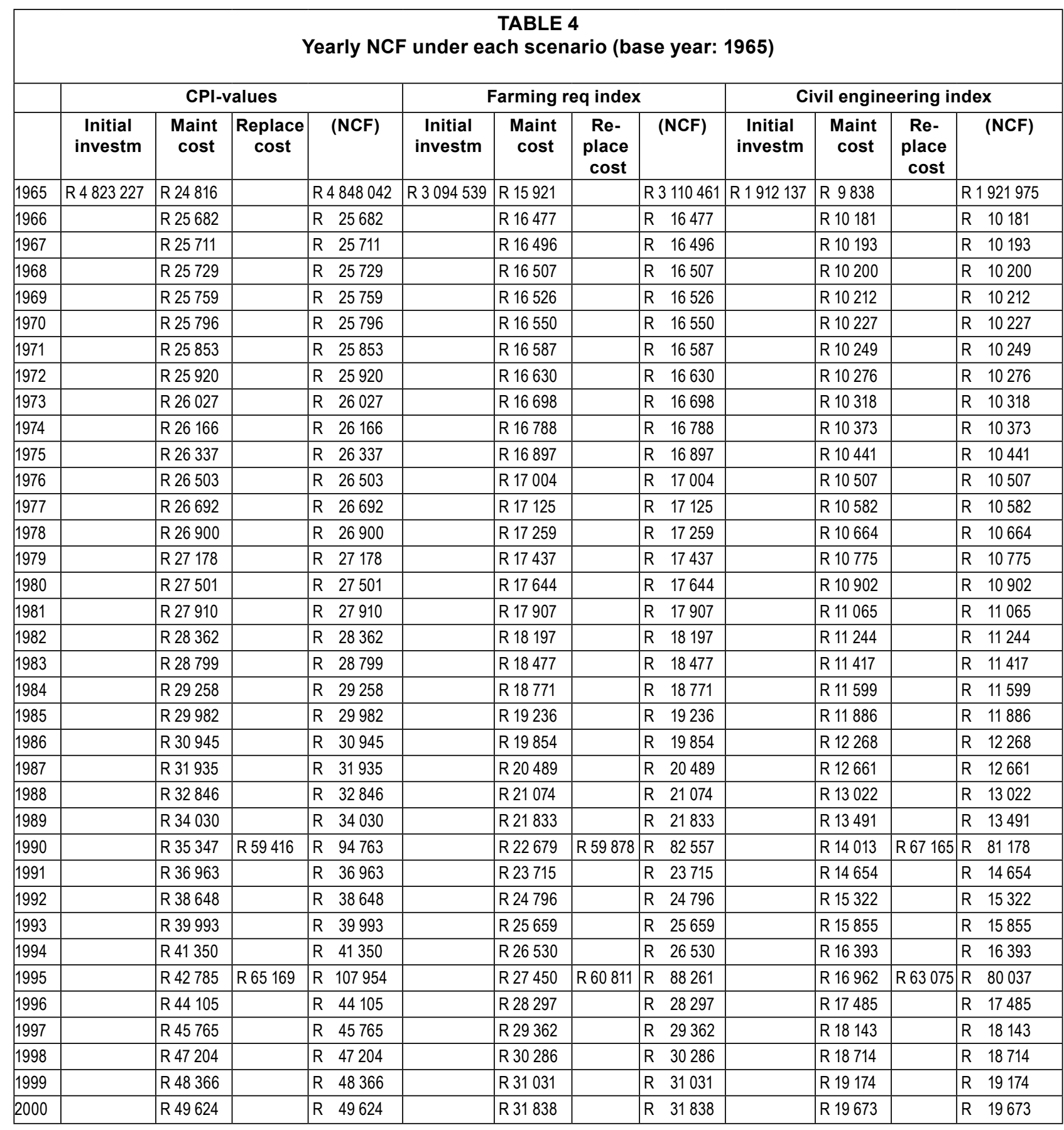

In spite of these difficulties, the guidelines have been adapted and applied to a case study scheme in South Africa. The results demonstrate the high costs of irrigation services compared to the low income, which is usually derived from irrigation by prevailing subsistence farmers. These results support the approach adopted by the Department of Water Affairs and Forestry (DWAF) in South Africa regarding the water pricing system, which includes the phasing-in of charges, waiving of options and ceiling principles regarding 'depreciation charges' (see Box 1). It must be highlighted here that the proposed depreciation charge is based on water use, as per $\mathrm{m}^{3}$. Furthermore, subsidies on O\&M charges will be phased out over 5 years, and farmers should pay for full O\&M costs from then onwards.

In contrast to charges, capital-cost subsidies will be granted to WUA members on a per-hectare basis. There is still uncer- tainty as to how such subsidies will be applied in practice since very few WUAs have been formally established in smallholder irrigation schemes to date. Subsidies for periodic rehabilitation or modernisation are indeed still needed, and yet Vermillion and Sagardoy (1999) warn that they should be re-designed so as to stimulate, not discourage, investment in maintenance by the water users. Recent history of smallholder irrigation in South Africa shows that massive rehabilitation/modernisation works are carried out at times (e.g. every 20 years or so) and are fully funded by the public sector, while much less effort is made in terms of human development, social capital and capacity building at the local level. Backeberg (2006) strongly promotes such investment, in view of the current situation. Regarding financing, Vermillion and Sardogoy (1999) promote the alternative of users contributing to a capital reserve fund (possibly com- 


\begin{tabular}{|c|c|c|c|c|}
\hline \multicolumn{5}{|c|}{$\begin{array}{c}\text { TABLE } 5 \\
\text { NPV per scenario and discount rate }\end{array}$} \\
\hline & & \multicolumn{3}{|c|}{ Discount rate } \\
\hline & & $\begin{array}{c}\text { Government } \\
\text { stock index } \\
(12 \%)\end{array}$ & $\begin{array}{c}\text { Government } \\
\text { bond index } \\
(7.4)\end{array}$ & $\begin{array}{l}\text { NCDs } \\
(6.5 \%)\end{array}$ \\
\hline \multirow{3}{*}{ 文 } & CPI-index NCF & -R 5076133 & -R 5218836 & -R 5264716 \\
\hline & Farming requisites index NCF & -R 3258716 & -R 3354242 & -R 3385175 \\
\hline & Civil engineering index NCF & -R 2016208 & -R 2080667 & -R 2101826 \\
\hline
\end{tabular}

\begin{tabular}{|c|c|c|c|c|}
\hline \multicolumn{5}{|c|}{$\begin{array}{c}\text { TABLE } 6 \\
\begin{array}{l}\text { Payment under each scenario and under each discount rate } \\
\text { (for the } 700-\text { hectare scheme under actual irrigation) }\end{array}\end{array}$} \\
\hline & & \multicolumn{3}{|c|}{ Discount rate } \\
\hline & & $\begin{array}{c}\text { Government } \\
\text { stock index } \\
(12 \%)\end{array}$ & $\begin{array}{c}\text { Government } \\
\text { bond index } \\
(7.4)\end{array}$ & $\begin{array}{l}\text { NCDs } \\
(6.5 \%)\end{array}$ \\
\hline \multirow{3}{*}{$\sum$} & CPI-index NCF & R 145032 & R 420780 & R 384652 \\
\hline & Farming requisites index NCF & R 398595 & R 270443 & R 247329 \\
\hline & Civil engineering index NCF & R 246616 & R 167758 & R 153564 \\
\hline
\end{tabular}

pleted with a matching fund by Government) so that incremental infrastructure improvement can take place. DWAF is striving to introduce the idea of a smallholder's contribution to the capital of the infrastructure they use. However, the proposed depreciation charges being based on $\mathrm{m}^{3}$ used (see Box 1), it seems inapplicable at the moment since no measuring device exists in smallholder irrigation in South Africa. Further, the few existing examples of charges to O\&M costs are based on irrigable land (a per-hectare basis) (Perret, 2002; Backeberg, 2006) and demonstrate a willingness to encourage more intensive use of irrigated land, in a context marked with significant non-farming tenure over irrigable land. It would be both unfair and inefficient to charge for capital cost recovery only on a water-use basis, penalising willing farmers, while all (including non farming occupiers) would benefit from subsidies granted on a per-hectare basis. Charging water-related costs on an 'irrigable land access' basis would constitute an incentive towards either intensification or land exchange, towards increased use of available infrastructures and water. Saleth (2002) stresses that under-utilised land and water capacity leads to an opportunity cost covering not only the output forgone but also the interest on investment.

At the moment, it seems, however, that the more urgent issue is to make farmers realise that at least O\&M costs should be covered (the so-called 'sustainability cost' promoted by Tardieu and Prefol, 2002), not only for the sake of a sustained functioning at present, but also to prevent future failures and quicker degradation, which may incur higher costs. As Saleth (2002) puts it '...low water charges and poor cost recovery risks the efficient maintenance of existing water infrastructure as well as the potential for additional investments on future water development projects. Declining water sector investments and deteriorating physical health of water infrastructure tend to depress the already declining economic contributions of water resources. In view of the close linkages among financial status, physical health and service quality, the economic performance of the water sector depends clearly upon its financial performance'.

Some key challenges that face irrigated agriculture, in South Africa and elsewhere, are economic in nature (Perret, 2006); this includes institutional and financial aspects. Numerous and recent factual experiences, observations and well-documented case studies throughout South Africa (Bembridge, 2000; Perret, 2002, Backeberg, 2003; Denison and Manona, 2006b, among others) challenge the usual political discourses underlying massive investments in smallholder irrigation (Denison and Manona, 2006a). It is clear that subsistence or non-commercial smallholder irrigation farmers are not significantly contributing to the supply of food, employment and livelihoods as well as multiplier effects in the local economy of rural areas. There is intense pressure on irrigated agriculture at large, to forgo all subsidies including those related to water resources, and to compete on a level field with other water users. Owing to their current situation, smallholder farmers must be granted support, opportunities and some time to become more productive if they are to join the mainstream economy (Backeberg, 2006). This further suggests considering costs, values and charges separately (Rogers et al., 1998; Briscoe, 1997; Tardieu, 2005), as well as avoiding charging smallholder farmers on a full cost recovery basis. Despite this, the time has probably come to consider water charges as incentives towards increased water and land productivity, improved maintenance and sound inner management in smallholder irrigation schemes, and not as deterrent measures or additional burden that should be shouldered by smallholder irrigators.

Application of the adapted calculation guidelines, using this paper's suggestions for South Africa, might be a first step towards more transparent and better-informed decisions on cost recovery strategies, subsidisation, and approaches in the smallholder irrigation sector

\section{References}

BACKEBERG G (2003) Water usage and irrigation policy. In: Nieuwoudt $\mathrm{L}$ and Groenewald $\mathrm{J}$ (eds.) The Challenge of Change: Agriculture, Land and the South African Economy. University of Natal Press, Pietermaritzburg, South Africa. 149-170.

BACKEBERG G (2006) Reform of user charges, market pricing and management of water: problem or opportunity for irrigated agriculture? Irrig. Drain. 55 1-12.

BEMBRIDGE TJ (2000) Guidelines for Rehabilitation of Small-Scale Farmer Irrigation Schemes in South Africa. WRC Report No. 
891/1/00. Water Research Commission, Pretoria, South Africa. BOUMA J, PALMA CR, FISHER J and RIEU T (2001) Cost Issues in the Water Framework Directive. European Community, Water Framework Directive, Articles 4, 5, 9 and Annexe III. Nov. 2001. $10 \mathrm{pp}$.

BRISCOE J (1997) Managing water as an economic good: Rules for reformers. Water Supply 15 (4) 153-172

BRISCOE J (1999) The financing of hydropower, irrigation and water supply infrastructure in developing countries. Water Resour. Dev. 15 (4) 459-491.

COSGROVE W and RIJBERMAN F (2000) A Water Secure World. World Water Vision, March 2000. Commission Report, The Hague, The Netherlands.

DENISON J and MANONA S (2006a) Principles, Approaches and Guidelines for the Participatory Revitalisation of Smallholder Irrigation Schemes. Vol. 1. A Rough Guide to Irrigation Revitalisation. WRC Report No. 1463/4. Water Research Commission, Pretoria, South Africa.

DENISON J and MANONA S (2006b) Principles, Approaches and Guidelines for the Participatory Revitalisation of Smallholder Irrigation Schemes. Vol. 2. Concepts and Cases. WRC Report No. 1463/4. Water Research Commission, Pretoria, South Africa.

FAROLFI S and PERRET S (2002) Inter-sectoral competition for water allocation in rural South Africa: Analysing a case study through a standard environmental economics approach. Proc. XXXIX Convegno SIDEA, Firenze, Italy. 12-14 September.

FIRER C, PEAGRAM J and BRUNYEE W (2003) Rebalancing strategies and the performance of balanced portfolios: 1925-2001. Invest. Anal. J. 58 17-28.

HOSKINS SG and DU PREEZ M (2004) A cost-benefit analysis of the Working for Water Programme on selected sites in South Africa. Water SA 30 (2) 143-152.

IBBOTSON RG and SINQUEFIELD RA (1989) Stocks, Bonds, Bills, and Inflation. McGraw-Hill, New York.

IMWI (2003) Irrigation Management Transfer: How to Make it Work for Africa's Smallholders? IWMI, Water Policy Brief Series Issue 11, $6 \mathrm{pp}$.

JAMIN JY, BISSON P, FUSILLIER JL, KUPER M, MARAUX F, PERRET S and VANDERSYPEN K (2005) La participation des usagers à la gestion de l'irrigation: des mots d'ordre aux réalités dans les pays du Sud. Les Colloques de l'Académie d'Agriculture de France Vol 1 ? Author ? (1) 65-83.

MORGENROOD P (1987) The treasury bill in South Africa 1881-1931. The Securities Markets 6 11-18.

MORGENROOD P (1988a) The treasury bill in South Africa 1931-1965. The Securities Markets 7 13-17.

MORGENROOD P (1988b) The treasury bill in South Africa 19651981. The Securities Markets 8 27-30.

MOHR PJ (1985) The De Kock Commission and inflation. SA J. Econ. 53 (4) 22-40.

ORTMANN G and MACHETHE C (2003) Problems and opportunities in South African agriculture. In: Nieuwoudt L and Groenewald J (eds.) The Challenge of Change: Agriculture, Land and the South African Economy. University of Natal Press, Pietermaritzburg, South Africa. 47-62.

PERRET S and TOUCHAIN E (2002) A Simulation-Based Approach to Assess the Economic Viability of Smallholding Irrigation Schemes in South Africa: Conceptualisation and First Implementation. Action - Research and Modeling. CIRAD Tera / UP research report, CIRAD-Tera, No. 02/02, Pretoria, SA.

PERRET S (2002) Water policies and smallholding irrigation schemes in South Africa: A history and new institutional challenges. Water Pol. 4 (3) 283-300.

PERRET S (2006) New paradigms, policies and governance in the water sector. In: Perret S, Farolfi S and Hassan R (eds.) Water Governance for Sustainable Development: Approaches and Lessons from Developing and Transitional Countries. EarthScan \& Cirad Publishers, London, UK. 11-14.

RIEU T and GLEYSES G (2003) Assessing the financial costs of water infrastructure and application to a raw water supply system in Guadeloupe Island (French West Indies). In: ICID Guidelines for Assessing Existing and Future Costs of Irrigation Services. ICID International Conference, $5^{\text {th }}$ Meeting of the Working Group on Socio-Economic Impacts and Policy Issues, September 15, 2003, Montpellier, France. 17 pp.

ROGERS P, BHATIA R and HUBER A (1998) Water as a social and economic good: how to put the principle into practice. Global Water Partnership - Technical Advisory Committee Background papers No.2, GWP/Sida Publishers, Stockholm, Sweden.

SALETH RM (ed.) (2002) Water Resources and Economic Development. Edward Elgar Pub., Cheltenham, UK.

SAMPATH RK (1992) Issues in irrigation pricing in developing countries. World Dev. 20 (7) 967-977.

TARDIEU H and PREFOL B (2002) Full cost or 'sustainability cost' pricing in irrigated agriculture. Charging for water can be effective, but is it sufficient? Irrig. Drain. 51 (2) 97-107.

TARDIEU H (2005) Irrigation and drainage services: some principles and issues towards sustainability. An ICID position paper. Irrig. Drain. 54 (3) 251-262.

TIERCELIN JR (Coordinator) (1998) Traité d'irrigation. Lavoisier, Tech \& Doc, Paris, France. 1011 pp

UNION OF SOUTH AFRICA (1955) Summary of the Report of the Commission for Socio-Economic Development of the Bantu Areas within the Union of South Africa (Tomlinson Commission). UG 61/1955, Government Printers, Pretoria, South Africa.

VAN KOPPEN B, MORIARTY P and BOELEE E (2006) Muliple-Use Water Services to Advance the Millennium Development Goals. IWMI Research Report No. 98, Colombo, Sri Lanka.

VERMILLION DL (1997) Impacts of Irrigation Management Transfer: A Review of Evidence. IWMI Research Report No. 11, Colombo, Sri Lanka.

VERMILLION DL and SAGARDOY JA (1999) Transfer of Irrigation Management Services. Guidelines. IWMI-FAO-GTZ Irrigation and Drainage Paper, num. 58, Rome, Italy. 98 pp. 